\title{
Rupture and continuity: the future of tradition in museology
}

\section{Bruno Brulon Soares}

\section{(2) OpenEdition \\ 12 Journals}

Electronic version

URL: http://journals.openedition.org/iss/1961

DOI: 10.4000/iss. 1961

ISSN: 2306-4161

Publisher

ICOM - International Council of Museums

\section{Printed version}

Date of publication: 1 August 2020

Number of pages: 15-27

ISBN: 978-2-491997-11-3

ISSN: 2309-1290

Electronic reference

Bruno Brulon Soares, "Rupture and continuity: the future of tradition in museology ", ICOFOM Study Series [Online], 48-1 | 2020, Online since 01 August 2020, connection on 08 August 2020. URL : http:// journals.openedition.org/iss/1961; DOI : https://doi.org/10.4000/iss.1961 


\section{Introduction}

\section{Rupture and continuity: the future of tradition in museology}

\section{Bruno Brulon Soares Universidade Federal do Estado do Rio de Janeiro, UNIRIO}

Recently in Museu do Índio, a national institution in Rio de Janeiro safeguarding an important part of Brazilian indigenous heritage, conservators discussed a new method for the preservation of ethnographic collections. Based on local knowledge, museum professionals considered using a chopped banana stem as a new technology for pest control in one of the museum's most sensitive reserves. According to one of the museum's conservators, this method helps to avoid the infestation of organic materials by alerting the staff to the presence of bugs. The stem is supposed to attract bugs and other pests before they reach the collections, a method adopted by some museums in Latin America as a provisional solution to the problem of infestations that are particularly dangerous for organic objects in ethnographic collections.

While manuals of conservation would recommend more traditional approaches to the matter of infestations, tradition itself needed to be reinvented in this case. The museum turned to alternative knowledge, changing its methods in the absence of other immediate resources. While some major institutions can rely on advanced technology to preserve their collections, many museums, particularly in tropical areas, must adapt their traditional role of merely embodying a national collective memory (Smeds, 2019) to find alternative ways to solve contemporary issues. In the example of Museu do Índio, an institution with a long history of indigenous participation - in exhibition, documentation and conservation - what is new or "modern" is the introduction of local knowledge for the better functioning of this museum that was born embedded in European tradition.

But what is tradition and what is the modern in museology? To answer this somewhat rhetorical question we would need to understand how museums and museology deal with time. In fact, the outdated opposition between modern and traditional, so rigidly defined in the West, has proven to be inadequate to explain the role and the functions of museums in the present. However, one cannot ignore that a linear perception of time as the steady march toward 
"progress" has marked the history of museums since the Enlightenment and colonisation.

As the anthropologist Johannes Fabian once noticed, "time may give form to relations of power and inequality", which was the case of social evolutionism and its material expressions in museums. Linear time, as a philosophical construct adopted by social sciences since the ${ }^{\text {th }}{ }^{\text {century, }}$ still exerts its effects over societies under the conditions of capitalist industrial production (Fabian, 2002 [I983], p.ix). According to the "politics of time", power relations are built into the definition of what is traditional, primitive and underdeveloped compared to the modern, civilised and developed in the world. Hence, a definition of time and the hierarchical categorisation of humanity that follows were in the foundations of anthropology but also in the foundations of the modern museum.

Tradition, as a notion that is based on linear time, has been used to affirm difference as both temporal and spatial distance. It implies a symbolic separation between past and present, or between different societies and populations subjected to different places in the temporal scale of progress and civilisation. In a way, tradition is related to authenticity, a notion that is also linked to the origin of museums. The conception of an authentic past (savage, tribal or peasant), according to Fabian, serves to denounce the "inauthentic present (the uprooted, évolués, acculturated)" (2002 [I983], p.II). Such a conception helps to define a rupture in time that locates in different places the subject of science and its objects of study.

Museology, in its own way, inherited this preconceived perception of cultural difference and diverse forms of knowledge according to linear time, inventing its own traditions based on this Western conception of philosophical time, materialised in museums' representations of the Other inside their traditional dioramas.

Theoretical museology was not exempt from such a heritage, which has been revised in contemporary critical essays. The ideology of developmentalism was significantly expressed in museological theory produced in the ig8os. For instance, a sense of progress, improvement and development was deliberately applied to museological discourse in ICOFOM's annual symposium of I988, held in India, where the theme debated was "Museology and developing countries - help or manipulation?". As stressed in Vinos Sofka's evaluation the following year, the debates on the "development of societies" considered not only "the historical point of view with respect to past experience of different countries but also today's accelerating and more complex changes all over the world" (Sofka, I989, p. I3). Over the years, ICOFOM authors would challenge the hegemonic idea that a person in an "underdeveloped" country could not produce any significative form of theoretical thinking because theory and science are commonly produced in the global North.

Insisting on the importance of lineal time in the prediction of museology's future, the proposed theme for the ICOFOM symposium of 1989 was "Fore- 


\section{Introduction}

casting - a museological tool? Museology and futurology". Yet futurology, the science to predict the future, couldn't ignore its authoritarian character and the ethnocentric principle behind it, argued Waldisa Rússio in her critical approach to the theme. The Brazilian author would condemn futurology as a tool for manipulation oriented to the interests of particular groups and nation-states, "especially the richest" (I989, p. 219-20).

Today, ICOFOM does not have the same perception of societies and museums - or of time itself - as the one expressed in the I98os. We have changed into another time of theoretical production in order to recognise that innovation might express itself in the reinvention of traditional practices in the everyday life of a museum, such as in the use of a banana stem as a method for conservation. Indigenous knowledge and community participation are, today, important dimensions of museum tradition, but they involve the constant possibility of change and adaptation aiming to respond to contemporary claims and to make decolonisation an ongoing practice.

The general theme for the ICOM Conference of 2019 in Kyoto, Japan, "Museums as cultural hubs: the future of tradition", was interpreted as a contemporary provocation of how the past is being reworked for the future. Evident in the ICOFOM debates in Kyoto was the implication of time in studies that interrogate museological traditions and possible futures. As many of the articles in this issue will show, even when we decide to rupture with time in its linear form, exposing the Western tradition in the museum's foundations, it is never easy to let go of some parts of the past that are paramount for our sense of continuity. The Kyoto Conference was a clear example that to change the future we need to first and foremost recognise the traditions that took us to the present, and then find a way to move on.

Novelty enters the museum in those moments when we realise that it is necessary to subvert tradition, turning to our anti-manuals of museology (Zavala, 20I2), and letting go of the strict definitions and rules that don't apply to immediate reality as it is presented to us. As Homi Bhabha notes, the newness of cultural practices and historical narratives enters the world through fragmentation and hybridity. This process demands the recognition of "in-between spaces" whose decentred subject is signified "in the nervous temporality of the transitional, or the emergent provisionality of the "present"' (I994, p. 216). The present, thus, is reinvented between tradition and innovation, and it is in the contradiction of tradition that museums, somehow, find a way to transform themselves toward the future.

This issue of ICOFOM Study Series is thus not about forecasting the future, nor is it about differentiating ourselves from the past. By addressing the future of tradition in museology, it deals with what can be created in the space in between tradition and the new, wherein lies the potential for innovation and improvisation that is part of the museum's daily work and constitutes the experimental disposition of museology in the present. 


\section{Tradition and the sense of continuity}

In a rhetorical approach, "tradition" could be understood as a set of techniques developed to enable the ancient orator, who spoke without a manuscript, to invent, organise, and recall the points and arguments of a speech and engage in communal debates (Yates, I966; Fabian, 2002 [1983]). Tradition, in this perspective, is a discourse about the past that serves to give meaning to present experiences by creating a sense of continuity. In the past, "traditions" in museums was a term used to refer to popular cultures (Rivière \& Cuisenier, 1972), and the notion of "traditional populations" is still commonly applied to indigenous peoples or African-descendants groups living in certain parts of the so-called contemporary world (Cunha \& Almeida, 2009).

However, in museology the "traditional museum" is an expression commonly used to denote an obsolete model that no longer responds to the needs of present societies. Thus "tradition" in museology refers, in many cases, to Modernity. The traditional form of the museum, as an institution based on material artifacts that serves the interest of the modern State, is an important part of our inherited imaginaries and one that influences museological studies to this day. Museology was traditional in its essence, in its simplistic definition at the beginning of the $20^{\text {th }}$ century as "the science of the organisation of the museum" (Augé, I93I, p.I048), until the development of its more reflexive expressions in the following decades.

As a modern institution, the museum was perceived more recently by museology as "an act of violence, a rupture with traditions" in certain societies where time was not defined accordingly to the Eurocentric logic materialised in museum collections (Konaré, 1987, p.I5I). Historical studies have exposed Modernity in museums and cultural heritage, along with its colonial consequences in different parts of the world (Poulot, I998; Pearce, 20I0; Mairesse, 20II), which has resulted in the development of a critical theory. Recent studies have criticised coloniality in the museological tradition (Brulon Soares \& Leshchenko, 20I8) and discussed the different forms of subverting and overcoming our colonial past, as we see in the studies presented by Bertin and Graff in this issue and also in Mellado \& Andrade's analysis of a "mestizo museology".

As some of the contributors to this issue will show, reflexive museology and critical theory are fundamental to the decolonisation of this academic discipline. In the analysis of National museums in young states of the Pacific, Marion Bertin demonstrates how the museum, as a Western heritage, has adapted in these societies, involving communities and indigenous groups in the representation of the Nation. Bertin argues that museums in the Pacific

\footnotetext{
I. Modernity here understood as the consolidation of colonial empires in Europe and its consequences, but also the subjugation of peoples and cultures in their fights for liberation, since their histories may be narrated mainly through colonial discourses produced by those in power (Mignolo, I995).
} 
islands, a painful heritage from colonial times, can be reinterpreted as a useful tradition working as a political instrument for reshaping the future. As an instrument for political affirmation and cultural representation, museums in the Pacific islands are now subverted in a postcolonial interpretation of their traditional practices, by involving community members in the conservation of collections and in the transmission of cultural heritage. By connecting with an ancient heritage materialised in pre-colonial collections acquired by Westerners, these museums are redefined in the present as spaces for the negotiation of references from the past.

A similar appropriation of the museum device is described by Julie Graff in her analysis of the exhibition Öndia'tahterendih, oubliées ou disparues: Akonessen, Zitya, Marie et les autres (Forgotten or Missing), presented at the Musée de la Civilisation du Québec in 2018 and curated by Sylvie Paré. The exhibition deals with Indigenous feminicide in Canada by presenting the works of ro artists honouring murdered Indigenous women, seeking to emotionally engage the audience and at the same time raising political awareness on a sensitive and commonly forgotten topic in museums. This example of an exhibition that denounces violence against Indigenous women by exposing the roots of colonialism through art bluntly shows how museums can be used to question tradition and to expose the past in order to transform the future.

Distancing themselves from the traditional interpretation of the colonial past in anti-colonial approaches, these studies attempt to prove that tradition is an organic part of the present and may be reshaped by museums for the benefit of victimised societies and groups. Indeed, this may indicate to the reader how much museological thinking has been transformed since earlier generations of ICOFOM thinkers and critics of colonialism, who perceived the museum as "the sanction of an open breach, the consequence of a disaggregation of social traditional structures" (1987, p. I5), in the words of Malian politician Alpha Omar Konaré, an important name in our tradition.

While some approaches to colonialism may propose a drastic rupture, others will envisage the possibility of hybridity between structures from the past and elements of change in the present. Leonardo Mellado and Pablo Andrade propose that theoretical framing and the definition of museology itself are part of a heritage that has proven to be mixed, hybrid or mestizo from a postcolonial perspective. The authors propose the concept of a "mestizo museology" based on a critical reflection of the Museo Histórico Nacional of Chile and its 2018 exhibition Museo Mestizo: Fundamentos para el cambio de guión. This mestizo character of a postcolonial museology refers to a conceptual and dynamic patchwork that allows the recognition and validation of diverse theoretical sources and methodological frames.

In the present of mestizo museology, past and future are mixed up and entangled in the reinterpretation of basic museum practices and procedures. Traditional functions of the museum, such as collecting, curating and exhibiting, are exer- 
cised in a new light and for new goals. Based on this example, we can deepen our reflection on the different senses of tradition and traditionalism. By distancing itself from traditionalism, the museum may become mestizo by including new subjects to legitimise their cultural heritage - such as indigenous heritage, the heritage of African diaspora, or the heritage of the peasant. Mellado \& Andrade call attention to the fact that the "mestizo" is not commonly represented (or celebrated) in official memory. Hence, the need of a new configuration of the museum as the battlefield for new identities and for the undefined, mixed identities that are not materialised in their collections.

In her own interpretation of a mixed museology, Graff argues that the process of decolonising the museum cannot be accomplished without the work of Indigenous intellectuals and practitioners - a conception that is still not a tradition for institutions that reproduce exclusions along with the coloniality of power (Quijano, 200o), even when they speak of "decolonisation" from a Eurocentric point of view. As these authors will show, there is no transition into the future without the friction between past and present, which involves the recognition of tradition as an important part of museological heritage.

In the past few decades, from the most critical interpretations of the museum, museology has developed as a new reflexive tradition expressed in ICOFOM's publications and in the conception of a theory of museology. François Mairesse, in his introduction to this issue, interprets the collection of practices, representations, expressions and knowledges that constitute museology as an intangible heritage which is transmitted through generations of thinkers, beyond what is organised in published texts and manuals. He argues that museology has transmitted a methodological corpus that, over time, has produced the sense of a coherent academic discipline with shared values and particular challenges for the future.

The authors in this issue - as well as its editor - have learned to articulate their museological thinking by taking on the intangible heritage that was entrusted to them from past generations. ICOFOM was born in the late I970s as a reflexive committee questioning the basis of museum knowledge produced within the ICOM community. Today, after a few generations of theorists and researchers have left their legacy, we may look back to their work to find some wisdom. Looking into their texts and past reflections, the main lesson to be learned might be the realisation that critical thinking involves questioning the foundations of any acquired knowledge. But such a reflexive lesson needs time to be learned and to generate a tradition of its own. This issue of ICOFOM Study Series is a testimony to a new generation of thinkers who have learned the metamuseological lesson of questioning their own heritage and subverting tradition to create a museology of their own. 


\section{Ruptures and change: the sense of novelty}

Since the first wave of novelty in museological tradition, the movement of Nouvelle Muséologie in the I970s and I980s, museology has embraced a critical approach to the museum in its Eurocentric form inherited from the I $^{\text {th }}$ century (Varine, 20I7). This declared breach with the "traditional museum" allowed the recognition of new experiences that had in common an openness to cultural difference and social participation with no precedents in the history of museology.

New museology, as an international movement that was going to be absorbed as a new tradition to museology, or "a return to the basis of museology" (Devallées,1992), established an interpretation of time by dividing the history of this recent discipline between the old and the new based on a radical transformation in museum practices and ideologies. "Muséologie (nouvelle)", as conceived by André Desvallées and appropriated by other reflexive thinkers, proposed a rupture with tradition in a world that was being redesigned as "post-colonial" or "post-modern" - the newly hegemonic terms that were then spreading in social sciences.

Dealing with the multiplication of cultural differences related to a global crisis of values that followed the decline of modern utopias and the processes of decolonisation, new museology was born as a promise to rupture with the European universal narrative of progress and civilisation. Nevertheless, it still narrated the world of museums in terms of "new" and "old" practices, and it applied to museology the geopolitical division between developed and underdeveloped countries. As the Declaration of Quebec from 1984 would state: "new museology [...] is first and foremost concerned with the development of populations, reflecting the modern principles that have driven their evolution, while simultaneously associating them to projects of the future..." (italics mine). As we can see, the assistentialist attitude towards community-based museums was explicitly inspired by the evolutionist principle that defined development as the goal to be achieved by underdeveloped populations. In some contexts, such as South America, new museology and ecomuseology would transpose a hierarchy of power based on the centrality of the State to some experimental practices outside of the scope of traditional museology - in the periphery of the established museum field.

By applying the developmentalist logic of nation-states to the context of museums in the global South, new museology stressed the division between First, Second and Third worlds that was established between the I950s and 1975 when a new (hierarchical) global order was emerging (Pletsch, I98 I; Mignolo, 1995). Thus, the discourse of decolonisation in museology was not divorced from the reproduction of the capitalist structure of power based on the unequal distribution of resources, keeping the old designation of the First World as "purely modern, a haven of science and utilitarian decision making, technological, efficient, democratic, free" (Pletsch, I98I, p.574). 
What new methodology to use to better reflect on the museum and its plural expressions in the $2 \mathrm{I}^{\mathrm{st}}$ century? For Olivia Guiragossian in this issue, the future of museology relies on the future of research on museums and on the development of new instruments for observing museums in changing societies. The author's focus of analysis is museum observations themselves and the methods used to observe different forms and expressions under this traditional label. One of the first challenges for the observation of museums and the production of big data is the very definition of the museum in operational terms - as the author will point out.

Even though, in its roots, new museology was not a deliberate statement against "old" practices and theories, in some circles it was interpreted as a rupture with the modern structure of the museum - notably, with its most traditional form, as a building with material collections. As a result, it stressed the binary opposition between a visitor-oriented museum and a museum mainly concerned with the preservation of collections. This artificial breach between new and old would produce a sense of novelty in practices that considered the public as the museum-driven force while it reiterated the imaginary of an outdated museology. Several articles in this issue question the binary discourse that produces artificial oppositions in museological knowledge. In her rhetorical analysis, Elizabeth Weiser argues that the traditional dichotomy between visitor and object that is inscribed in the current ICOM museum definition has become obsolete in some recent approaches, which is clear in the textual analysis of the new definition of the museum proposed by ICOM to its General Assembly in 2019. Distancing herself from a dichotomy between "tradition" and "modernity", "old" and "new", Weiser prefers to critically consider the place of the museum within current museology in a more nuanced and broader sense.

Other investigations consider the importance of studies on material culture and the museum object as part of museology's heritage. In fact, studies on the museum object have been one of the central points of museological heritage until recently. Analyses such as the one presented by Nina Robbins in this issue emphasise the need for further research into this dimension of museological studies. Robbins proposes the concept of "object energy" to describe the written information surrounding a specific object in a museum.

In a parallel approach, Fabien Van Geert proposes a renewal of museological research considering geoheritage - geological heritage in its diversity. The author notes the theoretical challenges for museology regarding the in situ and ex situ preservation of geological heritage in France. Van Geert's article is valuable for calling attention to the lack of studies and publications on the topic of geoheritage in the main museological platforms and journals, a fact contrasted with the quantitative importance of this heritage in museums' reserves. One of the aspects pointed out in his analysis refers to the relation between theory and the fostering of new practices in a museological sense (involving both museums with traditional ex situ collections as well as geological heritage preserved in situ). 
As we look back to the "new" interpretations of museology that are now a part of our tradition, we cannot ignore the different forces that dispute the main foci in museological studies and discourses on the museum. The articles here presented help us to raise some questions about the future, considering that time is constantly reinventing itself. What are the traditions we want to keep and entrust to our future practices and reflections? What parts of the past should we hold on to and what parts are we ready to let go? These are questions that depend on the "breakdown of temporality" - as Bhabha describes it - in order to be answered, and they demand the recognition of museology as a discipline that operates in the in-between spaces that connect the old and the new, where traditions can be renegotiated before being transmitted to future generations.

\section{Transitioning into the future - once again}

Knowledge is always made of mixed, heterogeneous and even contradictory discourses, and in any given group or community, the affirmation of authority over knowledge imposes the separation between tradition and innovation, the legitimation of some established and stable references in their new altered configurations. After the heated debates in the Kyoto General Conference of 2019, it is not risky to predict that museology is in the verge of reinventing its traditions once again in the $2 \mathrm{I}^{\text {st }}$ century.

Museums today are facing new and unpredictable challenges that have set the tone for a more critical and experimental museology, whose tradition is being renegotiated while we reconsider our affiliations to the past. Far from the wish to forecast the future of museology, ICOFOM has intended, in its symposiums and publications, to map the different approaches to museological thinking that constitute our present. The anticipation of change in the museum world marked by the expansion of neo-liberal values and economic crises has been a constant concern, as expressed in the committee's debates a few years ago on the new trends in museology (Mairesse, 2015) - some of those trends already outdated as I write this introduction.

More than in any recent past, today we live a time of great uncertainty for museums and for museological reflections. This issue is part of a history of publications being launched in the middle of the COVID-rg pandemic, when most cultural institutions in the world are closed to the public and some effects of a long-term economic crisis are already haunting the museum field, with mass layoffs in some central institutions and cuts in salaries of the most vulnerable museum professionals. While the future of museums has been relegated to cyberspace - as a trend of the current pandemic discourse - this issue of ISS does not deal with our predicted virtual future. Most contributors to this publication have chosen to discuss the political implications of change related to the recent claims for social representations that are posing new issues for museums and for the interpretation of cultural heritage. 
But the current pandemic actually evinced some of the symptoms of a global transformation in the cultural, political and economic spheres that has been brewing long before the spread of coronavirus. While urban centres in the world, from Paris to Rio de Janeiro, deal with the appearance of "visible minorities" and the plurality of ways of living in society (Bancel et al, 2010, p. ro), cultural democracy as an ideal is being defied by the fragmentation of public space and the proliferation of differences and inequalities. Museums have to deal with an urgent crisis of representation caused by non-linear and ambiguous heritages and the discourse of decolonisation, including claims for the queerisation of their collections and practices, while still adapting to accelerated economic changes that lead to the precarity of work in the whole cultural sector.

Before the precipice of a new museum crisis, some questions can be left to the future of museology: how can our cultural institutions cope with the new economic reality and still be relevant for societies in the future? How can museums transition into the web and still find resources without a physical audience? Will museums still have the means and the staff to keep their material collections in expensive reserves while communicating and reaching new audiences online? For museums in every corner of the world, the current matters related to the economy of culture trigger an urgent debate on the redefinition of priorities. It is possible that museology, as the discipline that deals with values behind the museum institution, as Robbins suggests, has never been more valuable for the future of museums - a future that might depend on the traditions we decide to transmit right now.

While I write this introduction the very notion of what is modern and what is traditional is drastically changing. Advancing into the future, museums might need to reinvent themselves in societies where time is being re-written and re-presented in new forms through the manipulation of social facts, as part of a new political agenda for the $2 \mathrm{I}^{\text {st }}$ century. In her article in this issue, Luciana Menezes de Carvalho addresses the role of tradition in the "post-truth" era when the past is being re-negotiated for political reasons in the present. As an important part of modern tradition, museums are being challenged by negationist discourses that deny science and diminish the role of central institutions for the functioning of democratic societies. The new configuration of neo-liberal nation-states and their political power invents new traditions, disseminated through social media as the promise of a future that needs neither science nor scientists to exist - a reality that the COVID-I9 pandemics are already calling into serious question.

Critical thinking does not involve denying the past. On the contrary, it depends on looking at our traditions and recognising their presence in a critical way. As Carvalho states in her work, science is politically defined, and museology has defined itself as a scientific discipline based on a tradition of research and accumulated knowledge that is maintained by its actors in the present - as the beneficiaries of this intangible heritage. Part of museological critical thinking 
today is the very recognition of museology as a political arena where tradition is negotiated and transformed.

Some of the contributors to this issue, looking at museology from the peripheries of the global North - the traditional locus of knowledge production - have taken advantage of the breaches in tradition to propose innovative interpretations of current problems. Experimental museology, as explored by Melissa Aguilar Rojas in her article, encompasses the appropriation of museographic spaces with new practical expressions based on the sensory experience of visitors. The relation between theoretical museology and a practical method for experimental approaches to the museum is at the centre of Rojas' concerns. Focusing on the Latin American context, she emphasises how critical thinking associated with the use of technology may create opportunities "to hack the regular circuit of information". Hacking the museum, experimenting with it in different forms and in new social connections, may be an innovative way to recreate tradition while expanding its alternatives for the future.

One of the central points in Rojas' article is the fact that experimental museology exists beyond the museum - a statement that could be corroborated by several theorists in our tradition. In a different approach, Scarlet R. Galindo Monteagudo proposes an interpretation of museology through the lenses of Bruno Latour's Actor Network Theory (ANT) and symmetric sociology to demonstrate how the microanalysis of the museum may take into consideration the agency produced by humans and non-humans beyond its immediate physical reality. These studies will show, for instance, how museums exercise their role in societies, how they communicate to their audiences by creating bonds and producing social engagement.

In light of new shared values in present-day societies, one can assume that a museum is a relational place, locally based and dependent on social participation, possibly defined as postcolonial and postnational, not subjected to Eurocentric constructions - as Mellado \& Andrade propose in their analysis. But this somewhat utopian ideal of a democratising and decolonised institution may reveal its contradictions in the present. Even if museums are postcolonial and postnational in principle, we cannot ignore the importance of the State in securing their survival in times of economic uncertainties and political crisis. In most countries in the world, South and North, a great part of museum collections is a permanent part of the national heritage kept by the State since early Modernity.

The current existence of museums is greatly dependent on the ways we transmit cultural heritage today, a process that is related to values of the present, but that could also determine the future of museums. In times of uncertainties that proliferate in the cultural field, one can still ask: how can museums be updated towards a dynamic cultural world without being complacent with a cultural market that enhances social inequalities and the unequal distribution of heritage? How to guarantee the transmission of cultural heritage to all in 
a world where culture has a price and not everyone can pay for it? In other words, how can museums and museology evolve towards a future, without contradicting the traditions and commitments to society that define them in the present?

The reflections gathered in the following pages may help us to think of creative solutions for future museums and museologies. One possible alternative is to find ways to rupture with the past while still securing its transmission to future generations who will think on it and produce new interpretations of their own traditions made of their own conception of time. Museums, thus, should be the expression of both tradition and transmission, by exhibiting the tensions behind the different interpretations of the past that materialise a future susceptible of being changed, contested, re-written in the present. It is in the space in between tradition and transmission that the past can be reinvented to create a better future.

\section{References}

Augé, P. (Dir.). (1931). Larousse du XXe siécle. v. 4. Paris : Librairie Larousse, p.IO48.

Bancel, N., Bernault, F., Blanchard, P., Boubeker, A., Mbembe, A., \& Vergès, F. (20I0). Introduction: De la fracture coloniale aux ruptures postcoloniales. In Achille Mbembe et al., Ruptures postcoloniales. La Découverte, Cahiers libres, 2010, p. 9-34.

Bhabha, H. K. (1994). The location of culture. London and New York: Routledge.

Brulon Soares, B., \& Leshchenko, A. (2018). Museology in Colonial Context: A Call for Decolonisation of Museum Theory. ICOFOM Study Series, 46, 6I-79.

Cunha, M., \& Almeida, M. W. B. (2009) Populações tradicionais e conservação ambiental. In M. Cunha (Ed.), Cultura com aspas e outros ensaios (pp. 277300). São Paulo: Cosac Naify.

Déclaration de Québec (1984). Principes de base d’une nouvelle muséologie, Adoptée par le r I $^{\text {er }}$ Atelier international Écomusée / Nouvelle muséologie, Québec, le I2 octobre, 1984. Retrieved April I8, 2020 from http://www.minomicom.net/_old/signud/DOC\%20PDF/198402504.pdf

Desvallées, A. (1992). Présentation. In A. Desvallées, M.-O. de Bary, F. Wasserman (1992), Vagues, une anthologie de la nouvelle muséologie. (pp. 15-39). Macon et Savigny-le-Temple, W et Mnes, t.I.

Fabian, J. (2002 [1983]). Time and the other: how anthropology makes its object. New York: Columbia University Press.

Konaré, A. O. (I987). L'idée du musée. ICOFOM Study Series, I2, I5I-I55. 
Mairesse, F. (2015). New trends in museology, ICOFOM Study Series, 43a, I3-I5.

Mairesse, F. (20II). Musée. In A. Desvallées \& F. Mairesse (Dir.), Dictionnaire encyclopédique de muséologie (pp. 27I-288). Paris: Armand Colin.

Mignolo, W. D. (I995). La razón postcolonial: herencias coloniales y teorías postcoloniales. Revista Chilena de Literatura, 47, 9I-II4.

Pearce, S. (2010). The collecting process and the founding of museums in the sixteenth, seventeenth and eighteenth centuries. In S. Pettersson, M. Hagedorn-Saupe, T. Jyrkkiö, \& A. Weij (Ed.), Encouraging collections mobility. A way forward for museums in Europe (p.12-33). Kaivokatu: Finnish National Gallery.

Pletsch, C. E. (198I). The Three Worlds, or the Division of Social Scientific Labor, Circa I950-1975. Comparative Studies in Society and History, 23(4), 565-590. Retrieved April I8, 2020 from www.jstor.org/stable/ı78394

Poulot, D. (Dir.). (1998). Patrimoine et modernité. Paris : L'Harmattan.

Quijano, A. (200o). Coloniality of Power, Eurocentrism and Latin America. Nepantla: Views from South, I(3), 533-580.

Rivière, G. H., \& Cuisenier, J. (I972). Le musée des arts et traditions populaires, Paris. Museum International, XXIV(3), I8I-I84.

Rússio, W. (I989). Muséologie et futurologie : esquisse d'idées. ICOFOM Study Series, I6, 219-226.

Smeds, K. (2019). Introduction. In K. Smeds (Ed.), The future of tradition in museology. Materials for a discussion. Paris: ICOFOM/ICOM.

Sofka, V. (Ed.). (I989). Forecasting - a museological tool? Museology and futurology / La prospective - un outil muséologique? Muséologie et futurologie. Preprints to the ICOFOM Symposium in The Hague, The Netherlands. ICOFOM Study Series, I6.

Varine, H. de (20I7). L'écomusée singulier et pluriel. Un témoignage sur cinquante ans de muséologie communautaire dans le monde. Paris : L'Harmattan.

Yates, F. A. (1966). The Art of Memory. Chicago: University of Chicago Press.

Zavala, L. (20г2). Antimanual del museólogo. Hacia una museología de la vida cotidiana. México: UAM/INAH/Conaculta. 